\title{
Evaluation of the terrestrial impact of carbone 14 and tritium released by PWR
}

\author{
M. Fournier, F. Siclet ${ }^{1}$ and G. Gontier ${ }^{2}$ \\ IPSN/DPRE/SERNAT/LMRE, bâtiment 501, Bois des Rames, 91400 Orsay cedex, France \\ ${ }^{1}$ EDF-R\&D Laboratoire National d'Hydraulique et Environnement, \\ 6 quai Watier, 78400 Chatou, France \\ 2 IPSN/DPRE/SERNAT/LERCM, CEA Cadarache, batiment 153, \\ 13108 Saint-Paul-lez-Durance, France
}

\begin{abstract}
Within the scope of a joint IPSN/EDF research program, it is possible to present a statement of the environment out of industrial influence for two areas, one in the Nogent-sur-Seine region, the other around Dampierre, where seasonal sampling was monitored over two years. In Dampierre, the same sampling was implemented within areas exposed to atmospheric releases of the nuclear plant in order to assess the facility impact. The matrices selected for this specific survey include perennial self-sown vegetation (ivy leaves, meadow grass, blackberries), caducous tree leaves (durmast-oak), honey, game, cultivated fruits (apple), pasture grass, milk and cattle meat. The available quantity of results evidences a discrete marking effect by the facilities both in radiocarbon and tritium, but does not allow proposing a modeling.
\end{abstract}

\section{INTRODUCTION}

The radiocarbon and tritium activity in the terrestrial ecosystem has been measured from 1994 with various matrices (bryophyta, meadow grass, milk,...), within the scope of yearly and ten-year monitoring of the French nuclear plant. The available quantity of results evidences a discrete marking effect by the facilities both in radiocarbon and tritium, but does not allow proposing a modeling. Interpretation problems are due to the lack of zero point or baseline for both radio-elements, to the fact that they also are from natural origin and are involved in the water cycle and carbon cycle and, with regard to radiocarbon, to the contributions of nuclear weapon atmospheric tests. Within the scope of a joint IPSN/EDF research program, we present a statement of the environment out of industrial influence for two areas, one in the Nogent-sur-Seine region, the other around Dampierre. The site selected in the Nogent-sur-Seine region is considered as a reference site for this survey. In Dampierre, the sampling has undergone a seasonal monitoring over two years, and the same sampling was implemented within areas exposed to atmospheric releases of the nuclear plant in order to asses the facility impact. The matrices selected for this specific survey include perennial self-sown vegetation (ivy leaves, meadow grass, blackberries), caducous tree leaves (durmast-oak), honey, game, cultivated fruits (apple), pasture grass, milk and cattle meat.

\section{RADIOCARBON ABUNDANCE}

The results of the various sampled matrices are expressed in Becquerel per kilogram of carbon, noted as $\mathrm{Bq} . \mathrm{kg}^{-1} \mathrm{C}$. In order to incorporate the isotopic fractionation, and obtain comparable values for radiocarbon activity, the same results are expressed in $\Delta \%$ [1]. The measured activity is corrected by the isotopic fractionation, using the following equation $\{1\}$ :

$$
\mathrm{An}=\mathrm{A}\left(1-\left(2\left(25+\delta_{\mathrm{PDB}}{ }^{13} \mathrm{C} / /^{12} \mathrm{C}\right) / 1000\right)\right)
$$


where $\mathrm{A}$ is the measured activity, expressed in Becquerel; $\delta_{\mathrm{PDB}}{ }^{13} \mathrm{C} /{ }^{12} \mathrm{C}$ is the measured value of the isotopic ratio ${ }^{13} \mathrm{C} /{ }^{12} \mathrm{C}$ of the matrix considered in the Pee Dee Belemnitae scale; An represents the normal activity. The expression as $\Delta \%$ is obtained with the following equation $\{2\}$ :

$$
\left.\Delta^{14} \mathrm{C}=\left(\left(\text { An } \mathrm{e}^{\lambda(1950-p)}\right) / \mathrm{A}_{0}\right)-1\right) \times 1000
$$

where $\lambda=1 / 8267$ years $^{-1}$; $p$ is the sampling year; $A_{0}$ is the reference activity, expressed in Becquerel. The value of $\mathrm{A}_{0}$ is $226 \mathrm{~Bq} \cdot \mathrm{kg}^{-1} \mathrm{C}$.

The values obtained for spot samples of atmospheric carbon dioxide through sparging cannot be used in the current status of data. The problems met during implementation and operation of the cleaners might explain the varying results. Also, the values of the isotopic ratio ${ }^{13} \mathrm{C} /{ }^{12} \mathrm{C}$ measured on the carbon dioxide generated by the combustion of ground matrices are more negative than the expected values, in accordance with the bibliography $[2,3]$. The increase in atmospheric carbon dioxide by combustion of fossil products with a low value of isotopic ratio ${ }^{13} \mathrm{C} /{ }^{12} \mathrm{C}$ may have a relationship with this observation.

\subsection{Site in the Nogent-sur-Seine region}

The radiocarbon results for 1999 and 2000 are reported in en Bq. $\mathrm{kg}^{-1} \mathrm{C}$ and in $\Delta \%$ in table 1 .

Table 1: Results of samples on the Pierrelez, Sancy-les-Provins site.

\begin{tabular}{|c|c|c|c|c|c|c|c|c|c|c|}
\hline$\delta_{\mathrm{PDB}}{ }^{13} \mathrm{C} /{ }^{12} \mathrm{C}$ & Type & $\begin{array}{c}\text { Sample } \\
\text { date }\end{array}$ & $\begin{array}{c}\text { Activity } \\
{\left[\mathrm{Bq} \cdot \mathrm{kg}^{-1} \mathrm{C}\right]}\end{array}$ & $\pm 1 \sigma$ & $\Delta \%$ & $\pm 1 \sigma$ & $\begin{array}{c}\text { Activity } \\
{ }^{3} \mathrm{H}\left[\text { Bq. } \mathrm{l}^{-1}\right]\end{array}$ & $\pm 1 \sigma$ & $\begin{array}{l}\text { Activity }{ }^{3} \mathrm{H} \\
{\left[\mathrm{Bq} \cdot \mathrm{kg}^{-1} \mathrm{sec}\right]}\end{array}$ & $\pm 1 \sigma$ \\
\hline & Beef meat & $03 / 01 / 1999$ & & & & & $<1.22$ & DT & & \\
\hline \multirow[t]{2}{*}{-18.2} & Beef meat & $03 / 01 / 1999$ & 258.31 & 6.58 & 120.76 & 28.55 & 2.66 & 0.14 & 1.48 & 0.08 \\
\hline & Oak leaves & 09/01/1999 & & & & & $<1.21$ & DT & & \\
\hline \multirow[t]{2}{*}{-26.87} & Oak leaves & 09/01/1999 & 249.94 & 6.30 & 103.51 & 27.82 & 5.95 & 0.2 & 2.09 & 0.08 \\
\hline & Blackberries & 09/01/1999 & & & & & 1.44 & 0.14 & & \\
\hline \multirow[t]{2}{*}{-25.19} & Blackberries & 09/01/1999 & 251.20 & 6.36 & 105.36 & 27.99 & 6.82 & 0.4 & 3.06 & 0.18 \\
\hline & Beet leaves & 09/01/1999 & & & & & $<1.22$ & DT & & \\
\hline \multirow[t]{2}{*}{-26.74} & Beet leaves & 09/01/1999 & 251.01 & 6.36 & 107.94 & 28.07 & 2.56 & 0.13 & 0.62 & 0.03 \\
\hline & Milk & 09/01/1999 & & & & & 1.53 & 0.13 & & \\
\hline \multirow[t]{2}{*}{-16.32} & Milk & 09/01/1999 & 256.62 & 6.50 & 109.18 & 28.09 & 4.35 & 0.19 & 2.79 & 0.13 \\
\hline & Meadow & 09/01/1999 & & & & & 1.97 & 0.13 & & \\
\hline \multirow[t]{2}{*}{-27.17} & Meadow & 09/01/1999 & 248.50 & 6.29 & 97.80 & 27.79 & 1.7 & 0.12 & 0.68 & 0.05 \\
\hline & Ivy leaves & 09/01/1999 & & & & & 1.47 & 0.11 & & \\
\hline-30.95 & Ivy leaves & 09/01/1999 & 250.80 & 6.34 & 116.30 & 28.22 & 2.92 & 0.13 & 1.36 & 0.07 \\
\hline-24.9 & Blackberries & $09 / 27 / 2000$ & 251.20 & 6.29 & 104.71 & 27.52 & & & & \\
\hline-27.5 & Oak leaves & $10 / 05 / 2000$ & 252.57 & 6.34 & 116.52 & 27.89 & & & & \\
\hline-28.3 & Beet leaves & $10 / 05 / 2000$ & 245.46 & 6.15 & 86.81 & 27.10 & & & & \\
\hline-17.7 & Milk & $10 / 05 / 2000$ & 252.09 & 6.32 & 92.66 & 27.26 & & & & \\
\hline-27.8 & Alfalfa grass pasture & $10 / 05 / 2000$ & 246.08 & 6.17 & 88.48 & 27.16 & & & & \\
\hline-30 & Ivy leaves & $10 / 05 / 2000$ & 245.64 & 6.16 & 91.28 & 27.23 & & & & \\
\hline
\end{tabular}

The activity value obtained for beef meat, higher than the value obtained for the pasture grass sampled in 1999, may be due to the fact that the beef lived for several years with a varied food. The consistency of samples in ${ }^{14} \mathrm{C}$, expressed in delta per thousand, shows that the type of matrix has little influence on the result. The average value in $\Delta \%(107 \pm 28)$ obtained with grass and ivy leaves in 1999 is slightly higher than the value obtained in $2000(90 \pm 27)$. This decrease in ${ }^{14} \mathrm{C}$ activity might be related to an increase in atmospheric carbon dioxide on the sampling location. The overall average value in $\Delta \%$ is $103 \pm 28$. 


\subsection{Dampierre site out of influence}

The Dampierre site was studied with various sampling points located in areas out of influence. The radiocarbon results for 1999 and 2000 are reported in $\mathrm{Bq} \cdot \mathrm{kg}^{-1} \mathrm{C}$ and in $\Delta \%$ in tables 2 and 5. Excluding the atmospheric $\mathrm{CO}_{2}$ values, the overall average value in $\Delta \%$ is $103 \pm 28$.

Table 2: Results of samples on the Benne and Germigny-des-Prés sites.

\begin{tabular}{|c|c|c|c|c|c|c|}
\hline$\delta \mathrm{PDB}^{13} \mathrm{C} / 12 \mathrm{C}$ & Type & Sample date & $\begin{array}{c}\text { Activity } \\
{\left[\mathrm{Bq} \cdot \mathrm{kg}^{-1} \mathrm{C}\right]}\end{array}$ & $\pm 1 \sigma$ & $\Delta 0 / 00$ & $\pm 1 \sigma$ \\
\hline-10.90 & $\mathrm{CO}_{2}$ & $03 / 26 / 1999$ & 254.76 & 6.52 & 88.99 & 27.87 \\
\hline-22.10 & $\mathrm{CO}_{2}$ & $03 / 13 / 2000$ & 284.86 & 7.19 & 245.73 & 28.05 \\
\hline-20.10 & $\mathrm{CO}_{2}$ & $06 / 13 / 2000$ & 250.52 & 6.44 & 91.15 & 27.80 \\
\hline & $\mathrm{CO}_{2}$ & $12 / 05 / 2000$ & 253.34 & 6.37 & & \\
\hline
\end{tabular}

\subsection{Dampierre site under influence}

The Dampierre site was studied with various sampling points located in areas under influence, and most samples were performed $2 \mathrm{~km}$ south-south west from the site.

The radiocarbon results for 1999 and 2000 are reported in $\mathrm{Bq} \cdot \mathrm{kg}^{-1} \mathrm{C}$ and in $\Delta \%$ in tables 3 and 6.

Excluding the atmospheric $\mathrm{CO}_{2}$ values, the overall average value in $\Delta \%$ is $125 \pm 28$.

Table 3: Results of samples on the Lion-en-Sullias and La Tabarderie sites.

\begin{tabular}{|c|l|c|c|c|c|c|}
\hline$\delta \mathrm{PDB}^{13} \mathrm{C}^{12} \mathrm{C}$ & Type & Sample date & $\begin{array}{c}\text { Activity } \\
{\left[\mathrm{Bq}^{\left.-k g^{-1} \mathrm{C}\right]}\right.}\end{array}$ & $\pm 1 \sigma$ & $\Delta \%$ & $\pm 1 \sigma$ \\
\hline-14.12 & $\mathrm{CO}_{2}$ & $03 / 26 / 1999$ & 270.63 & 6.91 & 164.50 & 27.65 \\
\hline-21.10 & $\mathrm{CO}_{2}$ & $03 / 13 / 2000$ & 252.60 & 6.39 & 102.43 & 28.89 \\
\hline & $\mathrm{CO}_{2}$ & $06 / 13 / 2000$ & 233.13 & 5.96 & & \\
\hline-25.00 & $\mathrm{Miel}$ & $08 / 28 / 2000$ & 253.97 & 6.42 & 117.11 & 28.11 \\
\hline & $\mathrm{CO}_{2}$ & $09 / 26 / 2000$ & 271.15 & 6.80 & & \\
\hline
\end{tabular}

\subsection{Impact}

The value in $\Delta \%$, slightly higher than the value in the area out of influence, allows assessing the impact of a plant operating four 900 MWe sections: the concentration added to the terrestrial ecosystem close to the facility varies from less than 2 to a maximum of $6 \mathrm{~Bq} \cdot \mathrm{kg}^{-1}$ of carbon.

\section{TRITIUM ABUNDANCE}

The matrices are analyzed for the tritium content of free water and tritium content of hydrogen bound to the matrix. The tritium content of hydrogen bound to the matrix is measured on the water generated by combustion. The results are expressed in Bq. $\mathrm{L}^{-1}$. With regard to the tritium content of hydrogen bound to the matrix, the results also are expressed in $\mathrm{Bq} \cdot \mathrm{kg}^{-1}$ of dry matter. The values at detection threshold are identified as DT. 


\subsection{Site of the Nogent-sur-Seine region}

The results of the tritium activity for matrices sampled in 1999 are reported in tables 1 and 4 . The high discrepancies observed between free tritium and bound tritium activities for oak leaves and blackberries may be due to high evaporation conditions in drained environment. The overall average value for free tritium is $1.4 \mathrm{~Bq} . \mathrm{L}^{-1}$ and the overall average value for bound tritium is $3.6 \mathrm{~Bq} . \mathrm{L}^{-1}$.

Table 4: Tritium activity for samples on the Pierrelez, Sancy-les-Provins site.

\begin{tabular}{ccccccr}
\hline Tritium type & Sample date & Type & $\begin{array}{c}\text { Activity } \\
{\left[\mathrm{Bq} . \mathrm{I}^{-1}\right]}\end{array}$ & $\pm 1 \sigma$ & $\begin{array}{c}\text { Activity } \\
{\left[\mathrm{Bq}_{\mathrm{kg}} \mathrm{kg}_{\mathrm{sec}}\right.}\end{array}$ & $\pm 1 \sigma$ \\
\hline Free tritium & $09 / 01 / 1999$ & Apples & $<1.21$ & DT & & \\
Bound tritium & $09 / 01 / 1999$ & Apples & 1.98 & 0.12 & 0.97 & 0.06
\end{tabular}

\subsection{Dampierre site out of influence}

Due to the availability of the various matrices, the Dampierre site was studied with various sampling points located in areas out of influence. The results of tritium activity for matrices sampled in 1999 and 2000 are reported in table 5. The first series of high values, obtained in 1999 for free tritium and bound tritium, correspond to an area very close to the river (Loire): the overall average value for bound tritium is $4.8 \mathrm{~Bq} . \mathrm{L}^{-1}$. Another area out of influence was selected. In this area, the overall average value for free tritium is $1.85 \mathrm{~Bq} . \mathrm{L}^{-1}$ and overall average value for bound tritium is $3.72 \mathrm{~Bq} . \mathrm{L}^{-1}$.

Table 5: Activity of samples on sites out of influence: Benne, Germigny-des-Prés and Saint-Martin d'Abbat.

\begin{tabular}{|c|c|c|c|c|c|c|c|c|c|c|}
\hline Sample date & Type & $\begin{array}{c}\text { Activity } \\
\left.{ }^{3} \mathrm{H} \mathrm{Bq} \cdot .^{-1}\right]\end{array}$ & $\pm 1 \delta$ & $\begin{array}{c}\text { Activity }{ }^{3} \mathrm{H} \\
{\left[\mathrm{Bq} . \mathrm{kg}^{-1} \mathrm{sec}\right]}\end{array}$ & $\pm 1 \sigma$ & ${ }^{8} \mathrm{PDB}^{13} \mathrm{C} /{ }^{12} \mathrm{C}$ & $\begin{array}{c}\text { Activity } \\
{\left[\mathrm{Bq} \cdot \mathrm{kg}^{-1} \mathrm{C}\right]}\end{array}$ & $\pm 1 \sigma$ & $\Delta \%$ & $\pm 1 \sigma$ \\
\hline 0101261999 & Ivy leaves & 3.02 & 0.12 & & & & 250.56 & 6.36 & & \\
\hline 03261999 & Ivy leaves & 3.08 & 0.11 & 1.52 & 0.05 & & & & & \\
\hline 032619999 & Alfalfa grass pasture & 5.22 & 0.18 & & & & 249.06 & 6.33 & & \\
\hline 41060999 & Alfalfa grass pasture & 2.81 & 0.11 & 1.27 & 0.05 & & & & & \\
\hline (7) & Ivy leaves & 3.65 & 0.13 & & & & 254.51 & 6.45 & & \\
\hline Whind & Iry leaves & 7.37 & 0.23 & 3.66 & 0.13 & & & & & \\
\hline 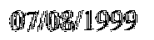 & Alfulfa grass pasture & 1.91 & 0.14 & & & & 257.42 & 6.52 & & \\
\hline 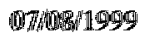 & Alffalfa grass pasture & 5.83 & 0.19 & 2.93 & 0.1 & & & & & \\
\hline 10\%11941909 & Meadow & 2.7 & 0.13 & & & -29.94 & 246.94 & 6.22 & 96.93 & 27.63 \\
\hline 1041911999 & Meadow & 6.41 & 0.21 & 3.35 & 0.12 & & & & & \\
\hline 1001190909 & Ivy leaves & 2.78 & 0.15 & & & -29.56 & 249.80 & 6.31 & 108.80 & 28.01 \\
\hline 116/19/11999 & Iwy leaves & 7.44 & 0.21 & 3.91 & 0.13 & & & & & \\
\hline 028202000 & Honey & 2.81 & 0.13 & & & -25.70 & 249.00 & 6.29 & 96.78 & 27.67 \\
\hline $002 / 2821000$ & Honey & 1.97 & 0.15 & 1.1 & 0.08 & & & & & \\
\hline 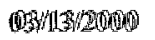 & 歌atter wapot & $<1.23$ & DT & & & & & & . & . \\
\hline OSW13/2000 & Al & 2.61 & 0.12 & & & & 243.12 & 6.13 & & \\
\hline 03 (n) 32000 & 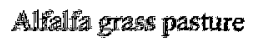 & 1.52 & 0.11 & 0.72 & 0.05 & & & & & \\
\hline $06013 \times 20000$ & Iwy leaves & $<1.22$ & DT & & & -31.56 & 247.88 & 6.26 & 104.64 & 428.11 \\
\hline $03 / 13 / 2000$ & Wow liedwes & 3.85 & 0.16 & 2.19 & 0.1 & & & & & \\
\hline 0671322040 & Iny leaver & $<1.13$ & DT & & & & 247.98 & 6.31 & & \\
\hline Oon13/2000 & INy ledrtes & 1.62 & 0.1 & 0.87 & 0.05 & & & & & \\
\hline 0926120000 & Allowlo gras pasture & $<1.19$ & DT & & & -29.20 & 245.43 & 6.15 & 88.62 & 27.88 \\
\hline
\end{tabular}




\begin{tabular}{lcccccccccc}
$09 / 26 / 2000$ & Ivy leaves & $<1.19$ & DT & & & -30.40 & 249.20 & 6.24 & 107.98 & 27.54 \\
$10 / 20 / 1999$ & Durmast-oak leaves & 1.65 & 0.15 & & & -30.27 & 249.88 & 6.31 & 110.71 & 31.29 \\
$10 / 20 / 1999$ & Durmast-oak leaves & 7.13 & 0.22 & 3.25 & 0.12 & & & & & \\
$10 / 20 / 1999$ & Blackberries & 1.34 & 0.11 & & & -27.44 & 251.37 & 6.36 & 111.08 & 27.76 \\
$10 / 20 / 1999$ & Blackberries & 3.18 & 0.14 & 1.45 & 0.07 & & & & & \\
$10 / 20 / 1999$ & Vegetables & 1.29 & 0.09 & & & -29.78 & 248.53 & 6.30 & 103.64 & 27.72 \\
$10 / 20 / 1999$ & Vegetables & 1.62 & 0.12 & 0.8 & 0.06 & & & & & \\
$10 / 20 / 1999$ & Milk & $<1.16$ & DT & & & -29.76 & 248.41 & 6.26 & 103.07 & 27.57 \\
$10 / 20 / 1999$ & Milk & 2.62 & 0.13 & 1.75 & 0.09 & & & & & \\
$10 / 20 / 1999$ & Alfalfa grass pasture & 1.35 & 0.13 & & & -29.92 & 247.05 & 6.23 & 97.37 & 27.14 \\
$10 / 20 / 1999$ & Alfalfa grass pasture & 5.6 & 0.22 & 2.59 & 0.11 & & & & & \\
$26 / 10 / 1999$ & Chicken & 1.28 & 0.11 & & & -24.16 & 251.48 & 6.35 & 104.31 & 27.61 \\
$26 / 10 / 1999$ & Chicken & 1.76 & 0.09 & 1.05 & 0.06 & & & & & \\
$09 / 26 / 2000$ & Blackberries & 1.39 & 0.11 & & & -27.50 & 249.66 & 6.26 & 103.65 & 27.91 \\
\hline
\end{tabular}

\subsection{Dampierre under influence}

The Dampierre site was studied with various sampling points located in areas under influence. The overall average value for free tritium is 1.54 Bq.L $\mathrm{L}^{-1}$ and the value for bound tritium is $3.69 \mathrm{~Bq} . \mathrm{L}^{-1}$. As regards bound tritium, it should be noted that this average value drops from $5.57 \mathrm{~Bq} . \mathrm{L}^{-1}$ in 1999 to $2.74 \mathrm{~Bq} . \mathrm{L}^{-1}$ in 2000 .

\subsection{Impact}

No significant discrepancy is detected between samples out of influence and under influence. This nonmarking might be due to the prevailing influence of supplies from the Loire river and the alluvial sheet loaded with tritium by the liquid discharges from plants on one side and by the oceanic rain water containing less tritium. It can be noted that tritium levels are globally higher in bound tritium than in free tritium, both within the area under influence and in the area out of influence.

\section{CONCLUSION}

The measurement of certain indicators such as meadows and ivy leaves allows detecting the radiocarbon impact of the plant. With regard to the reference site and the area out of influence, the average value of radiocarbon activity expressed in $\Delta \%$ is $103 \pm 28$. With regard to the area under influence, the average value of radiocarbon activity expressed in $\Delta \%$ is $125 \pm 28$. The impact of the plant discharges results in an increased radiocarbon concentration ranging from less than 2 to a maximum of $6 \mathrm{~Bq} \cdot \mathrm{kg}^{-1}$ of carbon, in the environment close to the plant. As for tritium, The edaphic, climatic and hydrologic natural conditions play a part in the distribution of these radionuclides and conceal the possible impact of plant discharges into the terrestrial ecosystem.

\section{Acknowledgement}

Vincent Mataix, Alain Champelovier, Nathalie Coreau and Aline Maigret for their contribution to this survey. 
Table 6: Activity of samples on Dampierre sites under influence: Lion-en-Sullias and La Tabarderie.

\begin{tabular}{|c|c|c|c|c|c|c|c|c|}
\hline Sample date & $\begin{array}{c}\text { Activity } \\
{ }^{3} \mathrm{H} \\
{\left[\mathrm{Bq} \cdot \mathrm{L}^{-1}\right]}\end{array}$ & $\pm 1 \sigma$ & $\begin{array}{l}\text { Activity }{ }^{3} \mathrm{H} \\
{\left[\text { Bq. } \text { kg }^{-1} \mathrm{sec}\right]}\end{array}$ & $\pm 1 \sigma$ & ${ }^{8} \mathrm{PDB}^{13} \mathrm{C}^{\prime 2} \mathrm{C}$ & $\begin{array}{c}\text { Activity } \\
{\left[\mathrm{Bq} \cdot \mathrm{kg}^{-1} \mathrm{C}\right]}\end{array}$ & $\pm 1 \sigma$ & $\Delta \% \quad \pm 1 \sigma$ \\
\hline 03/26/1999 Ivy leaves & $<1.37$ & DT & & & & 252.57 & 6.41 & \\
\hline 03/26/1999 Ivy leaves & 3.99 & 0.16 & 2.13 & 0.09 & & & & \\
\hline 03/26/1999 Alfalfa grass pasture & $<1.37$ & DT & & & & 253.25 & 6.41 & \\
\hline 03/26/1999 Alfalfa grass pasture & 1.92 & 0.13 & 0.9 & 0.06 & & & & \\
\hline 07/08/1999 Ivy leaves & 2.65 & 0.12 & & & & 254.72 & 6.45 & \\
\hline 07/08/1999 Ivy leaves & 8.32 & 0.25 & 2.54 & 0.1 & & & & \\
\hline 07/08/1999 Alfalfa grass pasture & 1.4 & 0.11 & & & & 257.02 & 6.50 & \\
\hline 07/08/1999 Alfalfa grass pasture & 6.28 & 0.21 & 2.39 & 0.09 & & & & \\
\hline 07/08/1999 Ivy leaves & 2.68 & 0.11 & & & & 261.12 & 6.61 & \\
\hline 07/08/1999 Ivy leaves & 8.58 & 0.25 & 5 & 0.16 & & & & \\
\hline 07/08/1999 Alfalfa grass pasture & 1.96 & 0.12 & & & & 267.78 & 6.78 & \\
\hline 07/08/1999 Alfalfa grass pasture & 4.37 & 0.15 & 2.2 & 0.08 & & & & \\
\hline 08/28/1999 Honey & 1.69 & 0.11 & & & & & & \\
\hline 08/28/1999 Honey & 1.83 & 0.16 & 1.11 & 0.1 & & & & \\
\hline 09/30/1999 Blackberries & $<1.16$ & DT & & & & 253.76 & 6.43 & \\
\hline 09/30/1999 Blackberries & 1.38 & 0.12 & 0.64 & 0.06 & & & & \\
\hline 10/20/1999 Milk & $<1.16$ & DT & & & -15.12 & 257.72 & 6.49 & 111.2128 .26 \\
\hline 10/20/1999 Milk & $<1.24$ & DT & $<0.76$ & DT & & & & \\
\hline 10/21/1999 Durmast-oak leaves & $<1.16$ & DT & & & -28.38 & 260.94 & 6.58 & 155.5428 .43 \\
\hline 10/21/1999 Durmast-oak leaves & 2.53 & 0.14 & 1.26 & 0.07 & & & & \\
\hline 10/21/1999 Vegetables & $<1.22$ & DT & & & -26.36 & 255.85 & 6.50 & 128.4527 .98 \\
\hline 10/21/1999 Vegetables & 1.72 & 0.11 & 0.78 & 0.05 & & & & \\
\hline 10/21/1999 Meadow & $<1.23$ & DT & & & -29.32 & 256.26 & 6.50 & 136.9329 .14 \\
\hline 10/21/1999 Meadow & 3.15 & 0.17 & 1.78 & 0.1 & & & & \\
\hline 10/21/1999 Ivy leaves & 1.98 & 0.13 & & & -31.71 & 256.71 & 6.48 & 144.3328 .67 \\
\hline 10/21/1999 Ivy leaves & 9.19 & 0.26 & 5.26 & 0.17 & & & & \\
\hline 10/22/1999 Duck & 2.48 & 0.16 & & & -20.65 & 256.70 & 6.50 & 119.3028 .84 \\
\hline 10/22/1999 Duck & 1.74 & 0.14 & 0.89 & 0.07 & & & & \\
\hline 03/13/2000 Water vapor & $<1.21$ & DT & & & & & & \\
\hline $03 / 13 / 2000$ Alfalfa grass pasture & 1.54 & 0.09 & & & -30.73 & 245.27 & 6.19 & $91.22 \quad 28.34$ \\
\hline 03/13/2000 Alfalfa grass pasture & 1.81 & 0.16 & 49.14 & 4.36 & & & & \\
\hline 03/13/2000 Ivy leaves & $<1.22$ & DT & & & & 256.83 & 6.49 & \\
\hline 03/13/2000 Ivy leaves & 4 & 0.17 & 2.23 & 0.1 & & & & \\
\hline 03/21/2000 Water & $<1.29$ & DT & & & & & & \\
\hline 06/13/2000 Meadow & $<1.24$ & DT & & & & 253.09 & 6.41 & \\
\hline 06/13/2000 Meadow & 1.73 & 0.12 & 0.88 & 0.06 & & & & \\
\hline $06 / 13 / 2000$ Ivy leaves & 1.53 & 0.1 & & & & 253.19 & 6.41 & \\
\hline 06/13/2000 Ivy leaves & 2.62 & 0.13 & 1.41 & 0.07 & & & & \\
\hline 09/26/2000 Blackberries & $<1.19$ & DT & & & -25.60 & 252.02 & 6.31 & 109.8727 .4 \\
\hline $09 / 26 / 2000$ Alfalfa grass pasture & $<1.19$ & DT & & & -27.90 & 256.23 & 6.42 & 133.6028 .26 \\
\hline $09 / 26 / 2000$ Ivy leaves & 1.47 & 0.13 & & & -31.60 & 254.84 & 6.41 & 135.7428 .43 \\
\hline
\end{tabular}

\section{References}

[1] Stuiver M., Polach H.A., Radiocarbon, 19 (1977) 355-363.

[2] Fritz P., Fontes J.Ch., ed., Handbook of Environmental Isotope geochemistry, v.1, The Terrestrial Environment, A. (ELSEVIER, 1980).

[3] Fritz P., Fontes J.Ch., Handbook of Environmental Isotope geochemistry, v.2, The Terrestrial Environment, B. (ELSEVIER,1986). 